Int. J. Speleol. 10 (1978), pp. 157 - 165

\title{
A note on the speleo-minerals in South Korea
}

\author{
by \\ N. KASHIMA*, M.S. SUH** and S.K. PAE***
}

The study area is a part of the most important karst area in South Korea, which lies in Gang Weon-do and Chung Buk-Do region which occupies the middle eastern part of the Korean Peninsula.

The formations affected by karstification belong to the Cambrian and the Ordovician limestones in the Joseon Supergroup.

According to Reedman et al. (1975), the middle Cambrian Daegi (Pungchon) limestone formation consists mainly of massive white and grey limestone with thin intercalation of shale and marl in the lower part, which thickens from $150 \mathrm{~m}$ to $300 \mathrm{~m}$; the upper Cambrian Hwajeol formation consists of interbeded limestone, sandstone, marl and shale. The limestone characteristically show a vermicular texture and the appearance of their wethered surfaces has led to them being refferred to as «worm eaten» limestones; and, the Ordovician Maggol limestone formation is composed of blue-grey massive to tabular limestone units containing a few thin shale bands, attain a total thickness of $200 \mathrm{~m}$ to $400 \mathrm{~m}$.

Although much biological and geographical studies have been done of the Korean speleology in this karst area, there still remain the mineralogical study of the speleothems.

During the summer of 1977, the writers visited the selected ten limestones caves in this karst area, investigating and sampling.

The purpose of this brief note is to report the mineralogical study of some speleo-minerals and should serve as a supplemet to the mineralogical data in South Korea.

\footnotetext{
*Department of Geology, Faculty of General Education, Ehime University, Matsuyama, Japan. ** Ajou Institute of Technology, Suwon, South Korea.

*** The Korean Association for Conservation of Cavern, Seoul, South Korea.
} 


\section{PRECEDING RESULTS.}

In 1966, Uéno et al. published a brief description on the results of speleological survey of twenty three caves and fourty nine wells in South Korea. It is reported that Hwaam-gul cave, Hwaam-ri, Dong-Myeon, Jeongseon-gun, Gang Weon-Do, contains the beautiful gypsum flowers.

In the southern volcanic island of South Korea, Cheju-do island, many lava caves have developed. Preliminary survey of the lava caves was carried out in the summer 1973 by three members from Japan and Korea. And Kashima (1973) reported that Ku Rin-gul cave contains exceptional phosphate mineral, taranakite.

In the summer of 1976, the speleological investigation of the karst area in Gang Weon-Do, Chung Cheong Buk-Do and Gyeong Sang Buk-Do, South Korea, was carried out by members of the Korean and Japanese speleologist. Although, only six caves were investigated, Suh et al. (1978) were able to take sixty two samples from three groups of speleo-minerals. They are carbonates (calcite, aragonite, dolomite and hydromagnesite), phosphates (brushite and hydroxyapatite) and sulfate (gypsum).

\section{GANG WEON-DO AREA.}

\section{LOCATION OF STUDIED CAVES.}

\section{1) Yong Dam-gul cave.}

Location: Byeolli-dong, Hadong-myeon, Yeong Weor-gun.

Latitude: $37^{\circ} 18^{\prime} 37^{\prime \prime}$ N.; longitude: $128^{\circ} 32^{\prime} 24^{\prime \prime} \mathrm{E}$.

Altitude: $420 \mathrm{~m}$.

Parent rock: Goseong-ri limestone (Age unknown).

The cave is one of the well known vertical caves in this area.

It is situated about $800 \mathrm{~m}$ north-east of the Go Si-gul cave at the opposite side of the Namhan River, on the right side of a small tributary.

\section{2) Yeon Hwa-gul cave.}

Location: Macha-ri, Dogye-myeon, Samcheog-gun.

Latitude: $37^{\circ} 19^{\prime} 02^{\prime \prime} \mathrm{N}$. ; longitude: $129^{\circ} 05^{\prime} 31^{\prime \prime} \mathrm{E}$.

Altitude: $360 \mathrm{~m}$.

Parent rock: Daegi (Pungchon) limestone.

Yeon Haw-gul cave opens to the right of a tributary of the Osib River. The cave has two entrances and one of the entrances has been utilized as a holy place for the Yeon Hwa Temple.

\section{3) Nog Ban-gul cave.}

Location: Habancheon-ri, Nogog-myeon, Samcheog-gun.

Latitude: $37^{\circ} 20^{\prime} 30^{\prime \prime}$ N.; longitude: $129^{\circ} 07^{\prime} 53^{\prime \prime}$ E. 
Altitude: $200 \mathrm{~m}$.

Parent rock: Daegi (Pungchon) limestone.

The cave entrance opens at the large rimstone pool in the south valley, near a tributary of the Osib River.

\section{4) Jeo Seong-gul cave.}

Location: Hagosa-ri, Dogye-myeon, Samcheog-gun.

Latitude: $37^{\circ} 16^{\prime} 47^{\prime \prime} \mathrm{N}$.; longitude: $129^{\circ} 02^{\prime} 53^{\prime}$ 'E.

Altitude: $220 \mathrm{~m}$.

Parent rock: Maggol limestone.

The cave is located in a tributary of the Osib River, approximately $1300 \mathrm{~m}$ east of Hagosari railway station. The cave contains a big hall and undergroundstream.

\section{5) Hoan Seon-gul cave.}

Location: Golmal, Daeidong-ri, Dogye-myeon, Samcheog-gun.

Latitude: $37^{\circ} 19^{\prime} 24^{\prime \prime} \mathrm{N}$.; longitude: $129^{\circ} 00^{\prime} 38^{\prime \prime} \mathrm{E}$.

Altitude: $500 \mathrm{~m}$.

Parent rock: Daegi (Pungchon) limestone.

The cave is one of the best known caves in this area, and is located on the steep eastern slope of the Taebaeg Mountain Range.

\section{6) Gwan Eum-gul cave.}

Location: Daei-ri, Dogye-myeon, Samcheog-gun.

Latitude: $37^{\circ} 19^{\prime} 18^{\prime \prime} N$.; longitude: $129^{\circ} 01^{\prime} 07^{\prime \prime} \mathrm{E}$.

Altitude: $360 \mathrm{~m}$.

Parent rock: Daegi (Pungchon) limestone.

The entrance opens on the right side of river $20 \mathrm{~m}$ above water level and 2000 $m$ west of the Daeidong elementary school.

\section{7) Hwal Gi-gul cave.}

Location: Hwal gi-ri, Miro-myeon, Samcheog-gun.

Latitude: $37^{\circ} 21^{\prime} 28^{\prime \prime}$ N.; longitude: $129^{\circ} 04^{\prime} 55^{\prime \prime} \mathrm{E}$.

Altitude: $150 \mathrm{~m}$.

Parent rock: Daegi (Pungchon) limestone.

The cave lies on the right side of a small tributary of the Osib River, about $1000 \mathrm{~m}$ by air, east of Gin Bae Mi-gul cave. 


\section{8) Gin Bae Mi-gul cave.}

Location: Hwal Gi-ri, Miro-myeon, Samcheog-gun.

Latitude: $37^{\circ} 21^{\prime} 49^{\prime \prime}$ N.; longitude: $129^{\circ} 05^{\prime} 27^{\prime}$ 'E.

Altitude: $80 \mathrm{~m}$.

Parent rock: Hwajeol limestone.

The cave entrance opens in the facing bluff of the railway in the Ryeongdongline, approximately $2500 \mathrm{~m}$ north of Singi Station.

\section{9) Baeg Yong-gul cave.}

Location: Maha-ri, Mitan-myeon, Pyeong Chang-gun.

Latitude: $37^{\circ} 16^{\prime} 20^{\prime \prime}$ N.; longitude: $128^{\circ} 34^{\prime} 36^{\prime \prime}$ E.

Altitude: $260 \mathrm{~m}$.

Parent rock: Maggol limestone.

The cave lies near the point were Yeong Weor-gun, Jeong Seon-gun and Pyeong Chang-gun meet. During the early age of the exploration, this cave was called Ma-Ha-gul cave. The cave is located in the west facing, limestone bluff of the Namhan River about 4500m upstream from Ma-Ha-ri. The cave contains three main passages which are named A, B and C-gul and are located different levels.

\section{CHUNG CHEONG BUK-DO AREA.}

\section{0) Geum Gang-gul cave (Cheon Dong-gul cave).}

Location: Cheondong-ri, Maepo-myeon, Dan Yang-gun.

Latitude:36 $58^{\prime} 02^{\prime \prime}$ N.; longitude: $128^{\circ} 25^{\prime} 32^{\prime}$ 'E.

Altitude: $340 \mathrm{~m}$.

Parent rock: Daegi (Pungchon) limestone.

It has an easily accesible cave entrance, an unpaved road leading about $5000 \mathrm{~m}$ southwest of the Go Si-gul cave.

\section{METHODS.}

Secondary cave minerals of fifty two samples from ten limestone caves were selected for study. Fig. 2 indicates the location of studied caves.

On return to the laboratory, all samples were dried in air, pulverized in an agate mortar and analyzed by X-ray diffraction methods.

$\mathrm{X}$-ray diffraction patterns of secondary cave minerals were obtained with NIHON DENSHI Co. LTD. JDX-8F equipment using Ni-filtered $\mathrm{Cu}-\mathrm{Ka}$ radiation at $35 \mathrm{KV}$ and $20 \mathrm{~mA}$. 


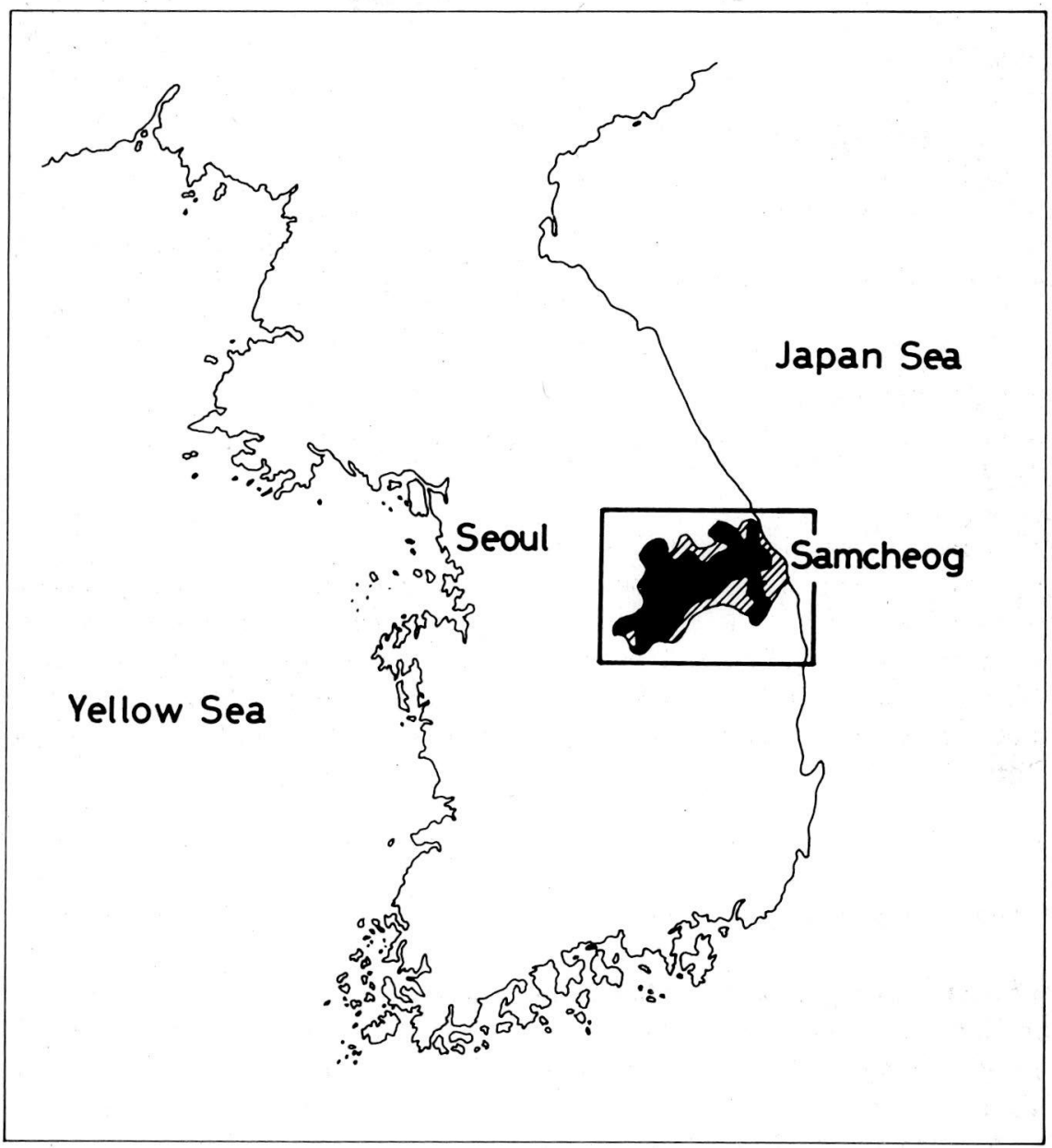

Fig. 1. - Index map of studied area in South Korea.

Black, Karst landform area; Oblique line, limestone area.

\section{ANALYTICAL RESULTS.}

$\mathrm{X}$-ray diffraction analyses revealed that five carbonate minerals and three phosphate minerals account for the fifty two samples.

Analytical results are summarized in Table 1.

The major carbonate minerals are calcite and aragonite; protodolomite (Magnesium-deficient dolomite), dolomite and hydromagnesite are the minor. $\mathrm{X}$-ray diffraction patterns show that few of the samples consist of a mixture of two or three minerals; 1 ) calcite + aragonite, 2) aragonite + dolomite and 3) calcite + aragonite + dolomite.

With regard to the phosphate minerals, hydroxyapatite is the most common in the studied caves, and brushite and taranakite are vary rare. 


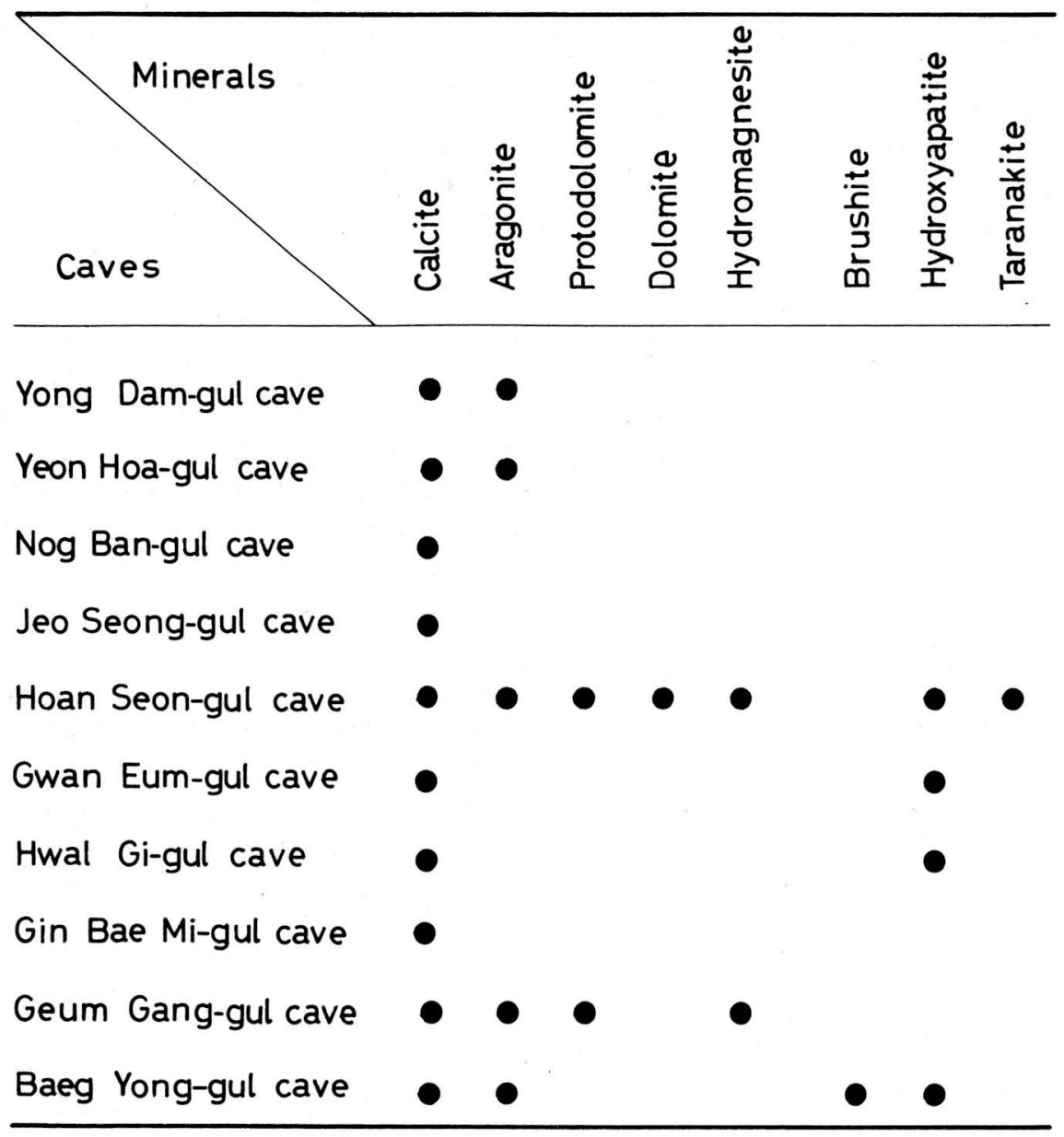

Table 1. - Analytical results of speleo-minerals in studies caves.

\section{DISCUSSION.}

The Hoan Seon-gul cave and Geum Gan-gul cave are the most well mineralized by interesting calcium-magnesium carbonate mineral assemblages in the studied caves.

In general, calcite-aragonite, polymorphs of calcium carbonate, is the most common speleo-mineral in the limestone caves, however, dolomites are quite rare. It has been found although that dolomite and protodolomite are not uncommon in these two caves. The six samples studied were thought to be dolomite, but five samples of them contain excess calcium dolomite and ranged from $\mathrm{Ca}_{0.57} \mathrm{Mg}_{0.43} \mathrm{CO}_{3}$ to $\mathrm{Ca} 0.52 \mathrm{Mg}_{0.48} \mathrm{CO}_{3}$. 
In the Hoan Seon-gul cave, hydromagnesite occurs as a white, soft, powdery floor deposit. And, in the Geum Gan-gul cave, it occures as white powder on the surface of stalactites and stalagmites. Such occurrences of hydromagnesite indicate that underground water has dried up and precipitated as a fine grained powder.

The occurrence and the evolutional crystallization of calcium-magnesium carbonate minerals in the limestone caves was first emphasised by Kashima (1977) and has been ratified in this work.

It is nortewothy that the important factors in cave mineralization processes of calcium-magnesium carbonates are $\mathrm{Ca}^{2+} / \mathrm{Mg}^{2+}$ ratio and $\mathrm{CO}_{2}$ concentration in speleothem-forming solutions. The compositional evolution of speleothemforming solution, there is double effect of decreasing the $\mathrm{CO}_{2}$ pressure, and of lowering ratio of $\mathrm{Ca}^{2+} / \mathrm{Mg}^{2+}$, and activating the crystallization of calcite, aragonite, protodolomite and dolomite in solution phase, and hydromagnesite in vapor phase.

Fig. 2 - Map showing the location of studied caves.

1: Young Dam-gul cave; 2: Yeon Hwa-gul cave; 3: Nog Ban-gul cave; 4: Jeo Seong-gul cave; 5: Hoan Seon-gul cave; 6: Gwan Eum-gul cave; 7: Hwal Gi-gul cave; 8: Gin Bae Mi-gul cave; 9: Baeg Yong-gul cave and 10: Geum Gang-gul cave.

Dotted line, the Joseon Supergroup area.

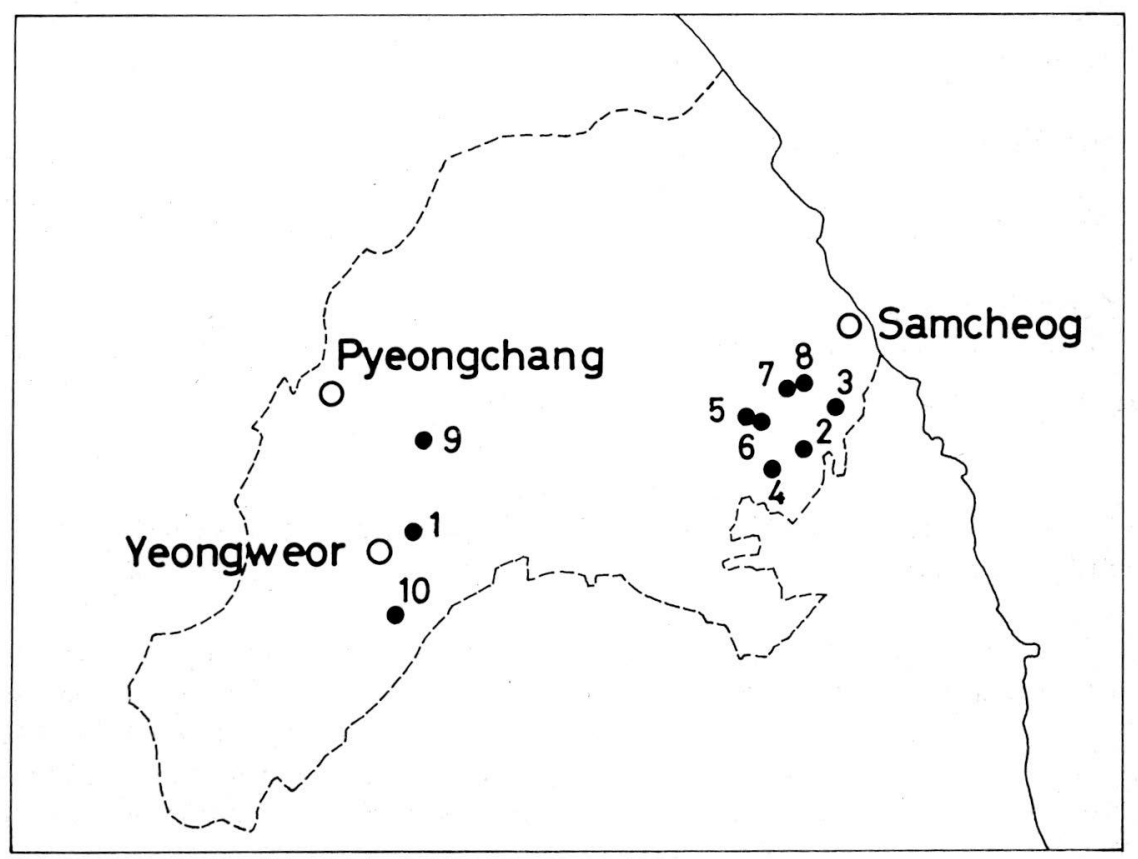


The phosphate minerals from only three species in these four limestone caves have been discovered, but these facts suggest that there is a possibility of discovering additional new phosphate minerals from the limestone caves in South Korea.

So far, we do not have enough field investigation and mineralogical analyses data of the speleo-minerals. Therefore, a great amount of detailed study of the mineralogy and chemistry of the speleo-minerals is needed.

Conclusively, the renewed speleo-minerals list and their localities in South Korea are given on Table 2.

Table 2. - Speleo-minerals and localities in South Korea.

\section{CARBONATE MINERALS}

\begin{tabular}{ll} 
Calcite & $\begin{array}{l}\text { Almost all limestone caves } \\
\text { Hyub Jae-gul cave and Ssan Young-gul cave (lava caves). }\end{array}$ \\
\hline $\mathrm{Aragonite}_{3}$ & $\begin{array}{l}\text { Seog Hwa-gul cave, Go Su dong-gul cave, Go Si-gul cave, } \\
\text { Young Dam-gul cave, Yeon Hwa-gul cave, Hoan Seon-gul ca- } \\
\text { ve, Geum Gang-gul cave and Baeg Young-gul cave. }\end{array}$ \\
\hline $\begin{array}{l}\text { Protodolomite } \\
\mathrm{CaMg}\left(\mathrm{CO}_{3}\right)_{2}\end{array}$ & $\begin{array}{l}\text { Seog Hwa-gul cave, Haon Seon-gul cave and Geum Gang-gul } \\
\text { cave. }\end{array}$ \\
\hline $\begin{array}{l}\text { Dolomite } \\
\text { CaMg }\left(\mathrm{CO}_{3}\right)_{2}\end{array}$ & $\begin{array}{l}\text { Seog Hwa-gul cave, Go Su dong-gul cave and Hoan Seon-gul } \\
\text { cave. }\end{array}$ \\
\hline $\begin{array}{l}\mathrm{Hydromagnesite} \\
4 \mathrm{MgCO}{ }_{3} \bullet \mathrm{Mg}(\mathrm{OH})_{2} \bullet 4 \mathrm{H}_{2} \mathrm{O}\end{array}$ & $\begin{array}{l}\text { Seog Hwa-gul cave, Hoan Seon-gul cave and Geum Gang-gul } \\
\text { cave }\end{array}$ \\
\hline
\end{tabular}

SULFATE MINERAL

Gypsum

$\mathrm{CaSO}_{4} \bullet 2 \mathrm{H}_{2} \mathrm{O} \quad$ Hwaam-gul cave and Seog Hwa-gul cave.

\section{PHOSPHATE MINERALS}

Brushite

$\mathrm{CaHPO}_{4} \bullet 2 \mathrm{H}_{2} \mathrm{O}$

Go Su dong-gul cave, Go Si-gul cave and Baeg Yong-gul cave

Hydroxyapatite

$\mathrm{Ca} 5(\mathrm{PO} 4)_{3}(\mathrm{OH})$

Seog Hwa-gul cave, Go Su dong-gul cave, Go Si-gul cave, Cho Dang-gul cave, Seong Ryu-gul cave, Hoan Seon-gul cave, Gwam Eum-gul cave, Hwal Gi-gul cave and Baeg Yonggul cave.

Taranakite

$\mathrm{H}_{6} \mathrm{~K}_{3} \mathrm{Al}_{5}\left(\mathrm{PO}_{4}\right)_{8} \bullet 18 \mathrm{H}_{2} \mathrm{O} \quad \mathrm{Ku}$ Rin-gul cave (lava cave) and Hoan Seon-gul cave

\section{ACKNOWLEDGMENTS.}

We are indebtes to Bureau of Cultural Property Ministry of Culture and Information of the admistration of South Korea for permission to carry out this investigation. We wish to thank The Korean Association for Conservation of Caverns and The Speleological Society of Korea for allowing us to conduct the field survey. We would also like to thank Mr. Jong Dae LEE, Mr. Sun Gab PAEK and Mr. Hiroshi MIYAMA for assistance in the field work.

One of the writers (N.K.) wishes to thank Professor Hitoshi MOMOI of Ehime University for the use to their X-ray equipment; and Miss Luana DARLOW for reading the draft. 


\section{REFERENCES}

HONG, S.H., 1976 - A study for the geographical distribution and its character of our natural cave. Sci. Rep. Kon Kuk Univ. 20: 47-86.

KASHIMA, N., 1973 - Taranakite: A supplement of general remarks on the cave phosphate minerals in Japan. Mem. Ehime Univ. Sci., [D]. 7: 73-77.

KASHIMA, N., 1977 - On some calcium-magnesium carbonate speleo-minerals in Yugoslavia and Korea. J. speleol. Soc. Japan. 2: 36-42.

REEDMAN, A. J. and S. H. UM., 1975 - The geology of Korea. Geological and mineral Institute of Korea. $139 \mathrm{pp}$, Seoul.

SHU, M.S. and N. KASHIMA., 1978 (in press) - Preliminary study on some secondary cave minerals in Korea.

THE KOREAN ASSOCIATION FOR CONSERVATION OF CAVERN, 1975 - The first report on the composite survey of the present state of the natural monument caves. $153 \mathrm{pp}$, Seoul.

UÉNO, S. I., S. K. PAE and F. NAGAO, 1966 - Result of the speleological survey in South Korea 1966. I. General account, with brief desrciptions of the caves visited. Bull. Nat. Sci. Mus. Tokyo. 9: 465-499, pls. 1-8. 